
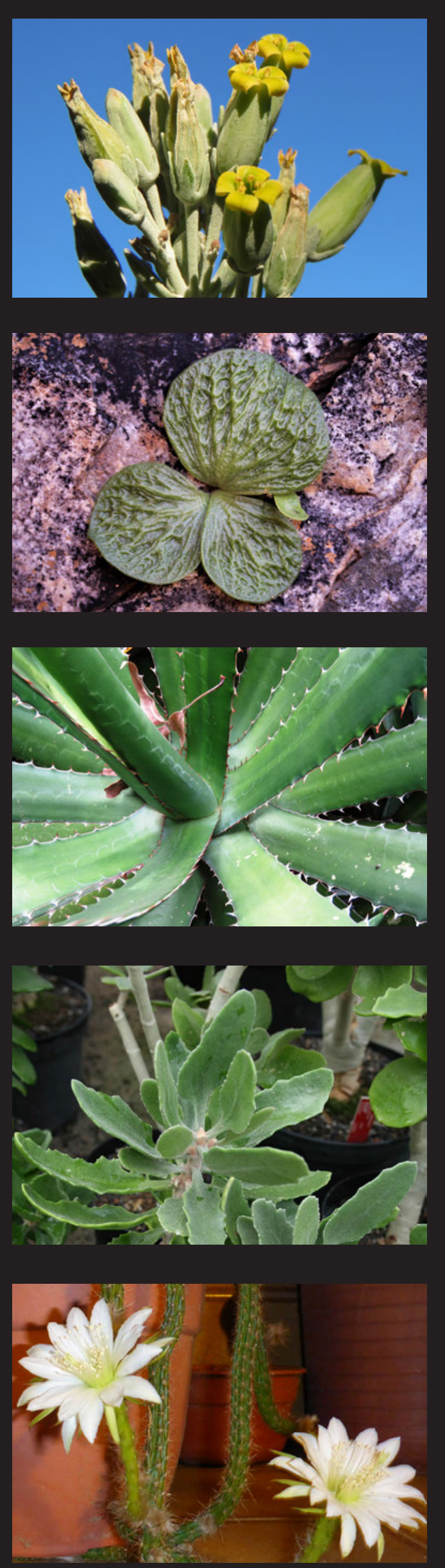

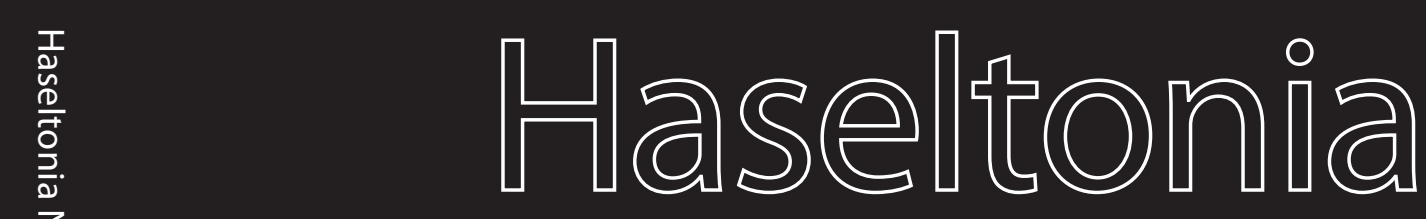

Yearbook of the Cactus and Succulent Society of America

Number 27
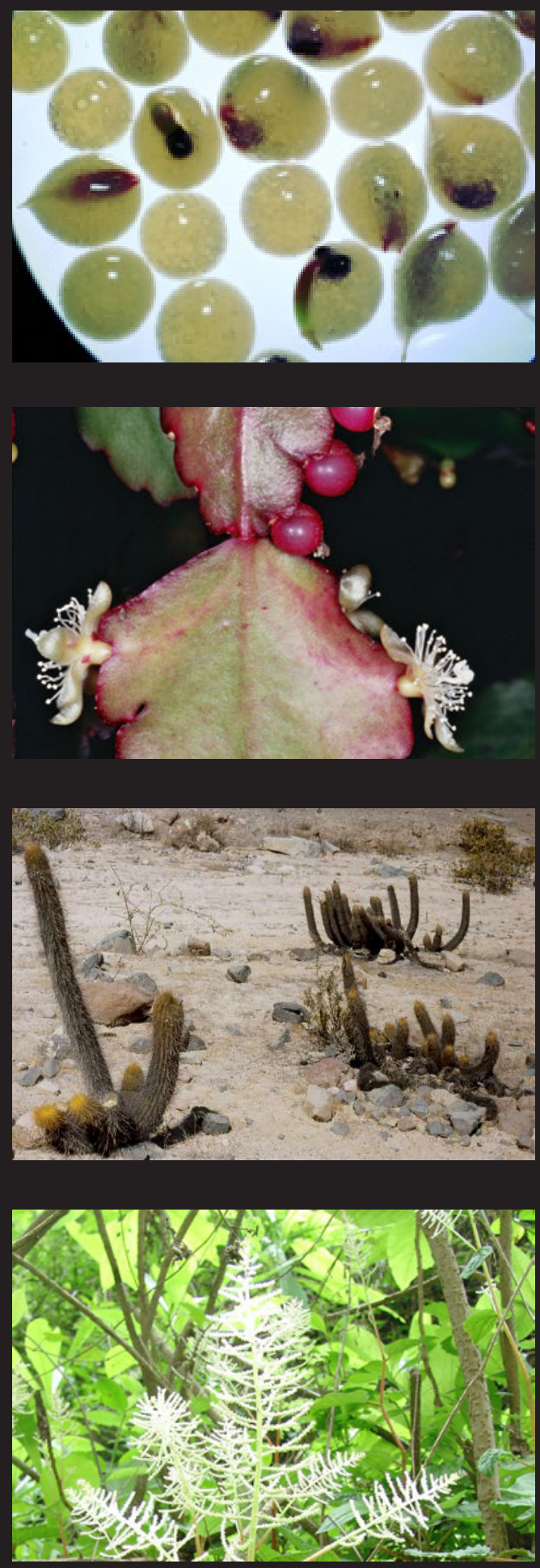

N

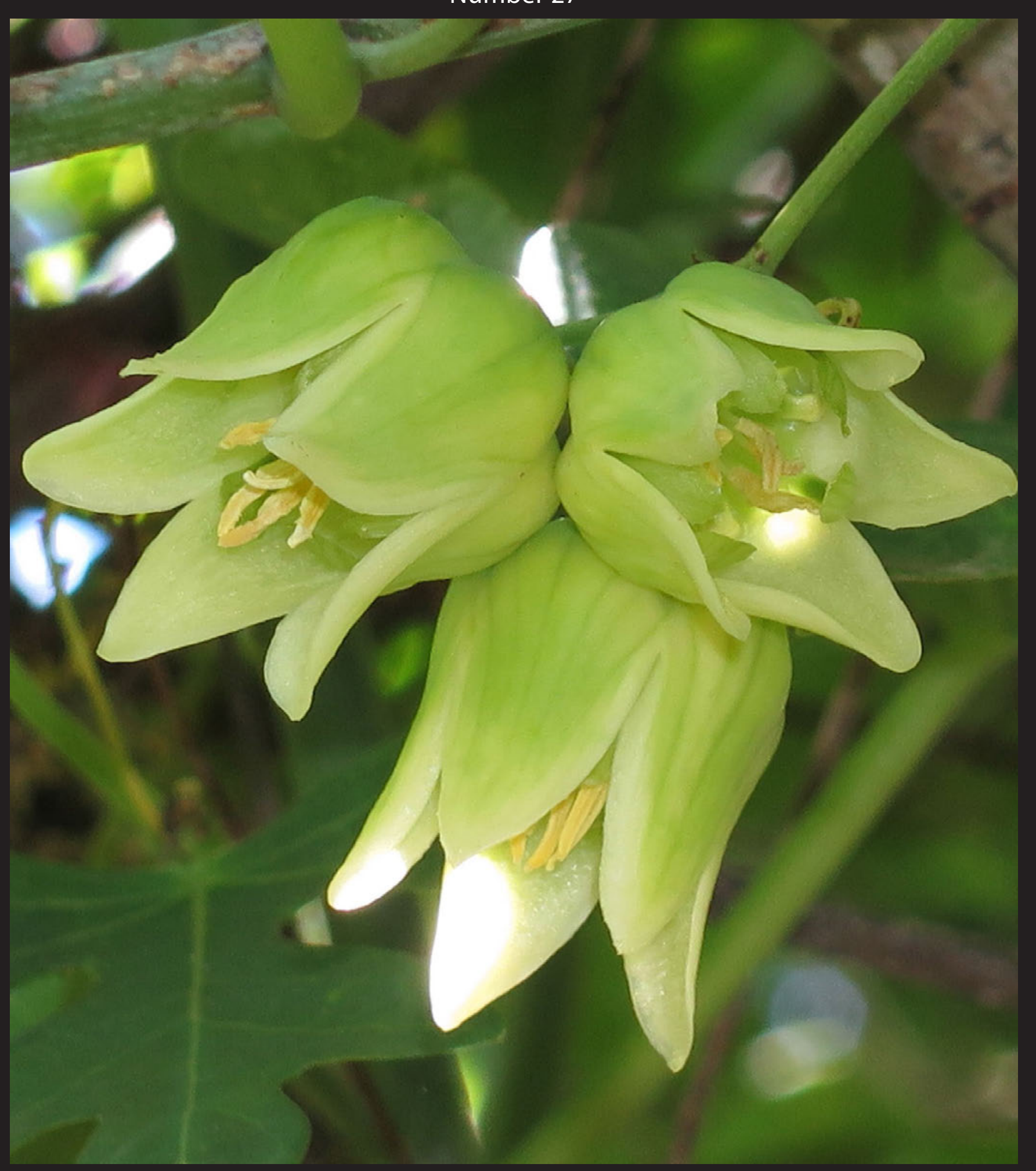


ISSN 1070-0048

EDITOR: JAMES MAUSETH

$$
\begin{aligned}
& 1110 \text { Blanco Street } \\
& \text { Austin, } \\
& \text { TX 78703 } \\
& \text { USA } \\
& \text { email: Haseltonia.Editor@gmail.com }
\end{aligned}
$$

\section{MANAGING EDITOR,}

DESIGN \& LAYOUT:

TIM HARVEY

$$
\text { css_editor@hotmail.com }
$$

\section{PRINTING LGI BINDERY}

Callahan, FL 32011, USA

Haseltonia is an annual, full-color, peer-reviewed publication of the Cactus and Succulent Society of America. Papers in Haseltonia are more technical than those in the Cactus and Succulent Journal, but all articles are written and edited such that they should be accessible to anyone interested in cacti and succulents, whether the reader is already a specialist or is new to these plants. Haseltonia features papers that are focused on all aspects of cacti, succulents and their habitats. Topics include anatomy and morphology, conservation reports, biogeography, biochemistry, cyto

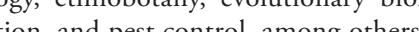

Most papers in Haseltonia are research reports that present the findings of research projects that generate new data, test hypotheses and fill gaps in our knowledge. Other papers are written as reviews that summarize our current understanding of a field of study. Some articles are introductions to subjects so as to make those submists, horticulturalists, and botanical libraries will all find Hoseltonia a valuble addition to their collection.

There are no page charges to publish in Haseltonia, even for color figures. Haseltonia abstracts are indexed on Science Citation Index, Current Contents, and Garden, available for download from BioOne (www pdioone-org). Authors wishing to publers in Haseltonid will find condensed instructions on the inside back cover and a detailed style gite ond or webste, actusendusculentseciety-org.

Papers and photos published in Haseltonia may be reprinted only with permission of the authors and photographers and must be properly cited.

Orders for current and back issues may be placed online (cactusandsucculentsociety.org), by email (gunnar.eisel@gmail.com), or sent by ordinary mail to our business office:

Cactus and Succulent Society of America,

PO Box 1000,

CA 91711 USA.

This issue was mailed $30^{\text {th }}$ December 2020.

\section{Front cover: Female flowers of Adenia natalensis. Photo by Neil R. Crouch.}

\section{Back cover:}

Left column, top to bottom: flowers of Kalanchoe crouchii; Tylecodon ectypus; Agave lophantha; Kalanchoe dinklagei; Trichocereus

Right column, top to bottom: Coryphantha sneedii var. villardii; synseeds of Ferocactus peninsulae; Rhipsalis rhombea; $\times$ Haagespostoa climaxantha; Peperomia ricardofernandezii. It will greatly assist the processing of manuscripts if authors will adhere to the
following guidelines when writing for Haseltonia. A more detailed style guide can be found on the CSSA website, cactusandsucculentsociety.org, by following the appropriate link.

Assemble the manuscript in the following order: 1. Title — include family names where appropriate; 2. Author $(s)$ names; 3 Author addresses, including mailing and email address; 4. Abstract; 5. Keywords; 6. Submission date; 7. Introduction 8. Materials and methods (when appropriate); 9. Results; 10, Discussion; 11 .

It is not necessary to format manuscripts according to Haseltonia style. Scientific names and those of books and Journals should be italicized throughout. Titles for all sections, Abstract and Keywords should be in bold, as should other labels (e.s. Figure 1, Table 2). Units should be separated from quantities, e.g. $5 \mathrm{~mm}$ not $5 \mathrm{~mm}$.

AUTHOR(S) ADDRESSES: Please use the minimum address necessary. Even if you are a member of an institute or center within a university, please avoid listing those names unless they are required to get a letter to you. Indicate corresponding autho name with an asterisk.

ABSTRACT: All papers should begin with a brief abstract of fewer than 200 word summarizing the content and conclusions (not just the intent) of the paper.

KEYWORDS: All manuscripts must have several keywords.

TEXT: Cite and number each figure and table sequentially in the order in which they appear in the text. Each reference cited in the text must be listed in the Literature Cited section (and vice versa). Hasehtonia uses the same references formar as the Journal of Evolutionary Biology for which formatting styles can be downloaded for use in EndNote, Mendeley, and other reference manager software.

ILLUSTRATIONS: Digital images are preferred and must be of high resolution (please see style guide for detailed instructions). Large image files should be submitted on disk or online. Small files $(25 \mathrm{Mb}$ or less) can be sent as separate

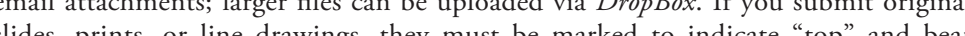
figure numbers. Original illustrations - but not duplicates or discs - will be returned once scanned. Low resolution figures are acceptable for the review process High resolution images are needed for accepted manuscripts. Photo credits are only necessary for non-authors.

The Editors reserve the right to modify the text of articles without changing its meaning, to improve radabihy, corct entrors or otherwise assist with layour over/under-exposure, etc. at the Editors' discretion.

SUBMISSIONS: Manuscripts should be submitted as an ordinary Word file to the Editor, Dr. James Mauseth, by email attachment (haseltonia.editor@gmail.com), DropBox or by regular mail (contact the editor for address). Along with the mantscript, authors should also send the names and email addresses of at least two people who could serve as potential reviewers for the manuscript.

PUBLICATION DEADLINE: Manuscripts for consideration in a given issue must be received by August $31^{\text {st }}$ of the year of publication

REPRINTS: A high-resolution pdf file will be provided to authors. 


\section{HASELTONIA}

Yearbook of the Cactus and Succulent Society of America

Number 27, 2020

\section{CONTENTS}

Kalanchoe Adans. subg. Fernandesiae Gideon F.Sm. (Crassulaceae subfam.

Kalanchooideae), a new subgenus from southern and south-tropical Africa

Gideon F. Smith

Tylecodon ectypus, a new cliff dwelling species from the Skaaprivier, northern

Namaqualand (Northern Cape Province), South Africa

Ernst J. van Jaarsveld \& Florent Grenier

The taxonomy of Agave lophantha Schiede (1829) and A. univittata Haw. (1831)

(Asparagaceae subfam. Agavoideae / Agavaceae) and the typification of both names

Joachim Thiede, Gideon F. Smith, Estrela Figueiredo \& Greg D. Starr

Notes on the natural geographical distribution range of the Madagascan Kalanchoe dinklagei Rauh (Crassulaceae subfam. Kalanchooideae)

Gideon F. Smith, Sven Bernhard, Joachim Thiede \& Martin Nickol

Mediocactus hahnianus: a resolved enigma and a new chapter of its history

Roberto Kiesling, Lidia Pérez de Molas, Luis Oakley, Daniel Schweich, M. Laura las Peñas, Aymeric de Barmon \& Detlev Metzing

The Coryphantha sneedii complex is indeed complex and continuously intergrades with Coryphantha vivipara

Root Gorelick

A reevaluation of the Agave kerchovei complex (Asparagaceae/Agavoideae) including expanded descriptions of three species

Greg D. Starr

Comparison of protein extraction methods from seeds of three Opuntia (Cactaceae) species

David I. Warren, Peter H. Quach \& Anne R. Gaillard

The dioecious Adenia natalensis W.J.de Wilde (Passifloraceae): discovery and description of the female

Neil R. Crouch \& David G.A. Styles

Synseeds for propagation and preservation of Ferocactus peninsulae (Cactaceae) and xeromorphic adaptations of seedlings

Manokari M., Priyadharshini S. \& Mahipal S. Shekhawat

Neotypification of Rhipsalis rhombea (Rhipsalideae, Cactaceae) and its taxonomic history

Ralf Bauer \& Nadja Korotkova

Examination of reticulate evolution involving Haageocereus and Espostoa

Mónica Arakaki, Pablo Speranza, Pamela S. Soltis \& Douglas E. Soltis

Ultra-thin hairy new shoots on belowground cuttings of recently rooted Cylindropuntia leptocaulis (Cactaceae)

Root Gorelick .....

Succulent Peruvian species of Peperomia subgenus Panicularia

Guillermo Pino, Ricardo Fernández \& Marie-Stéphanie Samain 


\title{
Mediocactus hahnianus: a resolved enigma and a new chapter of its history
}

\author{
Roberto Kiesling ${ }^{1 *}$, Lidia Pérez de Molas², Luis Oakley³, Daniel Schweich ${ }^{4}$, M. Laura las \\ Peñas ${ }^{5}$, Aymeric de Barmon ${ }^{6} \&$ Detlev Metzing ${ }^{7}$ \\ ${ }^{1}$ IADIZA-CONICET. C. C. 507. (5500) Mendoza. Argentina. \\ ${ }^{2}$ Universidad Nacional de Asunción, Facultad de Ciencias Agrarias (FCA-UNA). Paraguay. \\ ${ }^{3}$ Cátedra de Botánica, Facultad de Cs. Agrarias, Universidad Nacional de Rosario, Campo Experimental \\ José Villarino, C.C. 14, (2125) Zavalla, Santa Fe, Argentina. \\ ${ }^{4}$ Retired from CNRS, 5 rue J.Verne, 69330-Jonage, France. email: lobivia@cactuspro.com \\ ${ }^{5}$ Instituto Multidisciplinario de Biología Vegetal, CONICET (IMBIV), FCEFyN-UNC, C.C. 495, (5000) Córdoba, \\ Argentina. \\ ${ }^{6}$ ADBLPS, BP35, F-89140 Pont sur Yonne, France. info@adblps-graines-cactus.com \\ ${ }^{7}$ Federal Agency for Nature Conservation, Div. Plant Conservation, Konstantinstr. 110, 53179 Bonn, \\ Germany. email: detlev.metzing@bfn.de
}

* Author for correspondence: rkiesling@mendoza-conicet.gob.ar

Manuscript received $18^{\text {th }}$ September 2019

\begin{abstract}
The first discovery of Mediocactus hahnianus was attributed to Harry Blossfeld. Based on literature analysis, it is shown that T. Rojas and A.M. Friedrich plausibly made the discovery in the mid-1930s, and that seeds or cuttings were then given to Marsoner and eventually arrived at R. Blossfeld's nursery via H. Blossfeld. Although cultivated in Europe by Hahn, the plant is presently known only from the clone grown by J. West in the US, and obtained from Rojas in 1937. Recently, a new colony has been found and it seems to be a single clone. It perfectly fits the US clone from the point of view of morphology, flowers, growth habit, chromosome number, and seed morphology, whereas the localities are $400 \mathrm{~km}$ away from each other. Taxonomy and nomenclature are discussed: We decided to retain the species in Trichocereus, using a conservative concept for the genus based on morphological characters. A neotype for Mediocactus hahnianus is designated here.
\end{abstract}

Keywords: Cactaceae, Mediocactus hahnianus, Echinopsis, Trichocereus, Paraguay

\section{ORIGIN OF MEDIOCACTUS HAHNIANUS}

Mediocactus hahnianus has been described based on material that Harry Blossfeld is said to have sent to the Hahn nursery and that probably originated from Paraguay (Backeberg 1959: 795, 1962: 3653).

Robert Blossfeld, a horticulturist and seed trader in Berlin, was specialized in succulents and published several seed catalogs. In the catalogs dated February 1936, R. Blossfeld (1936: 3) mentioned a collecting trip his son Harry made in 1935 together with Oreste Marsoner in Argentina and Bolivia, and he added "...eventually in Uruguay and Paraguay...". Furthermore, at page 35 of the same catalog, one can read:

"The following unnamed species are available from the collecting trip of Harry Blossfeld through the South-American cacti regions... The most interesting collection of Paraguayan species (marked
Py.) from the battle-regions in the Chaco-Boreal will remain the sole and unique importation of these rarities...".

Seeds of five Cereus from Paraguay were offered on the same page. Perhaps the first one ("No. 200") could have been the later-named Mediocactus hahnianus, but the short mention of the white flowers, the creeping habit, and the reference to the Harrisia genus do not allow us to be certain; it may also have been a species of Monvillea, Harrisia or even Selenicereus.

More information on the South-American trip of 1935 is found in Harry's report, which was published both in German (H. Blossfeld 1936a), and English (H. Blossfeld 1935, 1936b). Therein he described in detail the travel together with Marsoner to W and NW Argentina. Near the last paragraph (H. Blossfeld 1935: 33, 1936b: 155) he briefly mentioned the activity after that trip: 
"To have time for this task [to collect at other areas], we separated in July [1935] and Herr Marsoner carried out the trip to Paraguay [previously] planned for later on and in a month of collecting obtained valuable material. Among them were cacti from the Chaco Boreal...".

The report makes it clear that Marsoner traveled to Paraguay, whereas H. Blossfeld did not, and the apparent contradiction to R. Blossfeld's statements in the 1936 catalogue is based on a simplification therein.

H. Blossfeld subsequently made further journeys, one to Bolivia, Peru, Ecuador and Colombia in 1936, and "a 3rd trip" to NE Argentina, NW Uruguay and $S$ of Brazil. Then he founded a nursery in the Brazilian state of São Paulo and later made further excursions, especially to search for orchids, his other interest (Secretaría de Verde e do Meio Ambiente 2012). No other reference was found to H. Blossfeld visiting Paraguay before or after 1936 .

So, we have to conclude that $\mathrm{H}$. Blossfeld never found $M$. hahnianus in Paraguay and that material of this species was probably obtained from an unknown source by $\mathrm{O}$. Marsoner, who collected in Paraguay on behalf of the R. Blossfeld nursery.

Further insight about the putative origin of $\mathrm{Me}$ diocactus hahnianus can be found in the book of Günther Moser (1985), which is based on the correspondence and photos sent by Adolfo Maria Friedrich, who collected plants and seeds in Paraguay. There are many references in the book to Friedrich's disappointments with Marsoner and the Blossfelds (Moser 1985: 13-15, 111-112, 117, 119, 137), as the plant findings of Friedrich were attributed to $\mathrm{H}$. Blossfeld and many mistakes were made regarding their habitats. Moser (1971: 4, 1985: 137) wrote

"all these discoveries made by Friedrich during the nineteen-thirties (1933-35) were bought up at the time by Oreste Marsoner on the instructions of Harry Blossfeld for the latter's father, Robert Blossfeld of Potsdam, near Berlin. However, the bulk of these plants actually went direct from Asuncion to the U.S.A. and Japan. And it was Yoshio Ito, the well-known Japanese cactus expert...".

Concerning Gymnocalycium friedrichii var. pazoutianum, Moser \& Valniček (1967: 9) and Moser (1985: 112) wrote

"the cactologist A.M. Friedrich, collected this variety in the years 1933-1935 in the northwest of Chaco Paraguayo ... O. Marsoner bought... all plants collected by A.M. Friedrich and these came over Harry Blossfeld to his father Robert Blossfeld to Potsdam, who later offered seeds of this species in his seed list (seed catalog) as 'seed type 0264-Py/Paraguay, Chaco, Piraretá...”.

The latter seed number is actually found in $\mathrm{R}$. Blossfeld (1936: 36). These citations confirm that the Paraguayan seeds sold by R. Blossfeld came from
A.M. Friedrich via O. Marsoner and H. Blossfeld. Mediocactus hahnianus may have been among this material. Hahn may have bought it from R. Blossfeld, and perhaps Backeberg got the plant in the 1950 s - in any case, he saw the plant at Hahn nursery (Backeberg, 1959: 795). Although partially speculative, this scenario reconciles the various parts of the story of the European original material.

In his paper about Harrisia hahniana Myron Kimnach (1987) mentioned that the plant studied by him was coming from "another collection" of this species, grown from seed brought back to the US by the American botanist James West in March 1937. The material (seeds or cuttings) has been taken from a specimen cultivated at the botanic garden in Asunción (Paraguay), that had been collected by Teodoro Rojas at NE Paraguay, Río Apa region, at 200 $\mathrm{m}$ [erroneously "2000 m"], on a limestone formation (according to West cited by Kimnach 1987). The amazing feature of this disclosure is that T. Rojas was a close friend of A.M. Friedrich! They both shared trips in the Paraguayan Chaco, Rojas as a botanist and Friedrich as a photographer as well as plant and seed collector. They made some of these trips during the "Chaco War", as members of some government commission to gather documentation about this little-known area. References to that friendship are repeatedly found in Moser (1985) and are mentioned as well in the biography of Rojas (Schinini 2005), where Rojas' trips devoted to plant collections are listed. Kimnach mentioned seeds as the collected material. However, different information is found in the catalogue of plants found by West that is preserved at the University of California Botanical Garden. At entry "Cereanea n ${ }^{\circ} 8498$ ", it is written "Pl. only collected" which probably means that West brought back a living cutting to the US. This may eventually explain why there is a single US clone available.

After the first description has been published, the original material from Hahn's nursery apparently has not been widely distributed in cultivation and it is even probably lost; maybe it was also grown from a cutting because Backeberg (1962: 3653) wrote "the plant should have been sent by Blossfeld jr. ... to Hahn...". The clone studied by Kimnach has been cultivated at the University of California Botanical Garden (Berkeley) since 1937 and since 1984 in Huntington Botanical Garden (San Marino, California), from where it has been generously propagated and distributed worldwide, by "International Succulent Introductions" in 1986 under the number ISI 1594 (HNT clone). Even, one of us had received a cutting of it some 30 years ago, from that institution, through the much appreciated and recently deceased Myron Kimnach. As a conclusion, it can be assumed that each $M$. hahnianus specimen in cultivation originates from the collection of $\mathrm{T}$. Rojas, who found the plant in the mid-1930s (perhaps together with Friedrich) and brought it to the botanical garden in Asunción. 


\section{THE REDISCOVERY}

When preparing the treatment of the Flora of Paraguay (unpublished), one of us (RK) noted the uncertainty about the origin of the plant, and the absence of recollection. Then, a trip to the junction of Río Apa with Río Paraguay had been organized in Sept. 2000, in a collaboration with several institutions (Facultad de Ciencias Químicas, Herbarium of the Universidad Nacional de Asunción [FCQ], Museo Nacional de Historia Natural del Paraguay [PY], Instituto de Botánica Darwinion [SI], and Jardin Botanique de Genève [G]). While the collection of herbarium samples from many plant families was surprisingly large, M. hahnianus could not be found. Probably it was overlooked during the collecting trip, or it does not grow in that area. Apparently, Rojas originally collected it more eastwards, perhaps in the Bella Vista area, some $150 \mathrm{~km}$ from there, where low sedimentary or calcareous hills also appear.

A few years ago (2009), Lidia Pérez de Molas found in the Paraguayan Chaco a cactus with a flower and a fruit — both hairy —, which might have been seen before without flower and thus confused with Monvillea cavendishii, which is widespread over all the area. Special attention was given to this plant, as the flower was very different from that of $M$. cavendishii, covered by long hairs, together with thin and more delicate stems and spines than in $M$. cavendishii. Having sent some photos to other authors (LO and RK), the plant was identified as Harrisia hahniana (as classified by Kimnach 1987). After that amazing finding, a special trip allowed us to find a colony of plants (Fig. 1) where we collected some small cuttings, which under cultivation freely produced a lot of new and long branches, as well as flowers. We suspect that the colony we found measuring about 20 to 30 meters in diameter, where very many broken stems had produced hundreds of individuals, all creeping and rooting, is a single clone. Searching around, no other colony has been found.

The stems (and later the flowers) of the new finding are in complete agreement with the clone studied by Kimnach (Fig. 2), and the excellent drawings he published in his 1987 paper, and with the illustrations we have seen, e.g. in Backeberg (1959: Abb. 713, 1962: Abb. 3320) and Hunt (2006: photo 235.2).

\section{DISTRIBUTION AND ECOLOGY}

The locality is situated in the dry woodland of the Chaco biogeographical region (Fig. 3), some $100 \mathrm{~km}$ before reaching Filadelfia coming from Asunción, in the Department Presidente Hayes. It is a few kilometers away from the Trans-Chaco route. The distribution area may be amazingly wider than expected, as the new discovery was made about $400 \mathrm{~km} \mathrm{SW}$ of the original locality cited by Kimnach (1987), if Rojas' information given to West was accurate.
The cactus is growing under the shade of the dense xerophytic woodland, so that it does not get much sun. Winter is the dry season, and rains are frequent in summer, with an annual average of 700 $\mathrm{mm}$, whereas the Río Apa zone where the first finding occurred has about $1200 \mathrm{~mm} /$ year (Metzing 1994). The soil is composed of alkaline, very thin clay (Esser 1982, Vogt 2011, and pers. obs.). In contradiction to Backeberg (1959), who characterized the plant as epiphytic, the notes accompanying the Rojas and West collection indicate that it grows as terrestrial (Kimnach 1987). The latter is confirmed by the rediscovery.

The associated vegetation at this locality is composed mainly of Achatocarpus praecox, Aspidosperma quebracho-blanco, Aspidosperma triternatum, Trithrinax schizophylla, Tabebuia nodosa, Ceiba chodatii, Anisocapparis speciosa, Capparicordis tweediana, Cynophalla retusa, Maytenus vitis-idaea, Acanthosyris falcata, Libidibia paraguariensis, Prosopis kuntzei, Prosopis ruscifolia, Prosopis sericantha, Bougainvillea praecox, Pisonia zapallo, Salta triflora, Sarcomphalus mistol and Castela coccinea. Other cacti there are Cereus forbesii, Cleistocactus baumannii, Echinopsis rhodotricha, Harrisia bonplandii, Monvillea cavendishii, Monvillea spegazzinii, Opuntia anacantha var. retrorsa, Opuntia discolor and Stetsonia coryne.

\section{TAXONOMIC RELATIONSHIP AND CLASSIFICATION}

Backeberg originally placed the species in the genus Mediocactus, due to its pendent habit (Backeberg 1959: 795). Later Backeberg (1962: 3653) confirmed this classification and justified this with the only slightly tubercled fruits, the habit and the origin from Paraguay. But he also mentioned the separate position of the species, due to the similarly spiny and hairy flowers in Selenicereus, which are not so slender or long.

Kimnach (1987) also pointed to the similarity of flowers and fruits of M. hahnianus and Selenicereus, although the latter genus "is not known southern of Venezuela and Colombia”.

Wallace (1997) used the same material of $M$. hahnianus from the Huntington Botanical Garden to study the species' phylogenetic position by the chloroplast marker rpl16. He deduced that the plant is an element of the genus Echinopsis (s. 1., including Trichocereus) and published the corresponding combination Echinopsis hahniana.

In a later phylogenic study, using four molecular chloroplast markers, Schlumpberger \& Renner (2012) grouped E. hahniana together with E. schickendantzii and E. thelegonoides in the Helianthocereus clade. The formal combination was published in the same year as Soehrensia hahniana (Schlumpberger 2012), as the genus name Soehrensia has priority over Helianthocereus.

Franck et al. (2013), using a combined matrix (two chloroplast and two nuclear markers), con- 

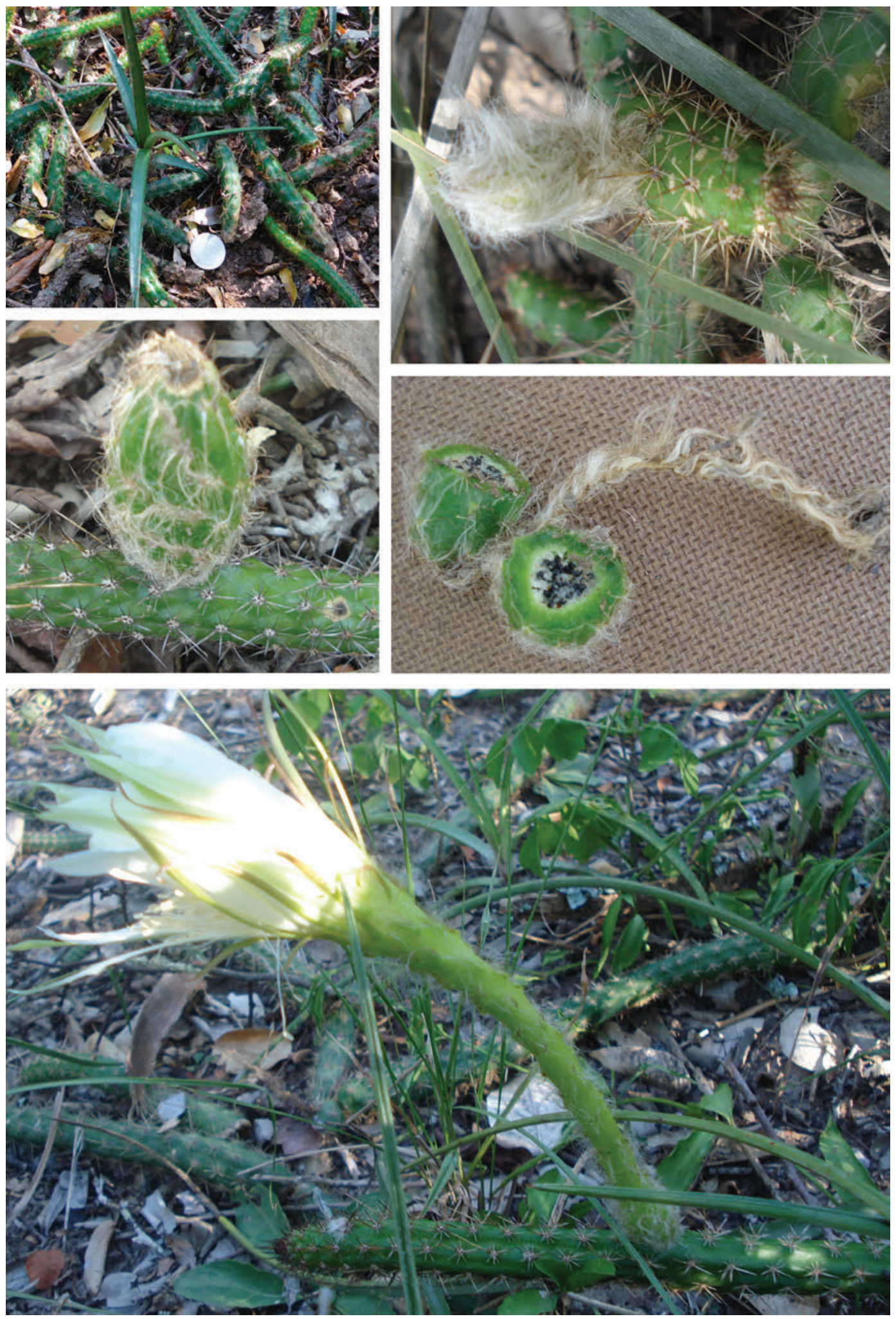

Figure 1. Trichocereus habnianus as rediscovered in the wild. Top left, many rooted stems together with a Bromelia sp. (the coin is $23 \mathrm{~mm}$ in diameter). Top right: flower bud. Middle left: full fruit. Middle right: fruit cut transversely (fruit not collected; seed maturity unknown). Bottom: flower. Picture, IIs L.P. de Molas except top right, R. Kiesling. 

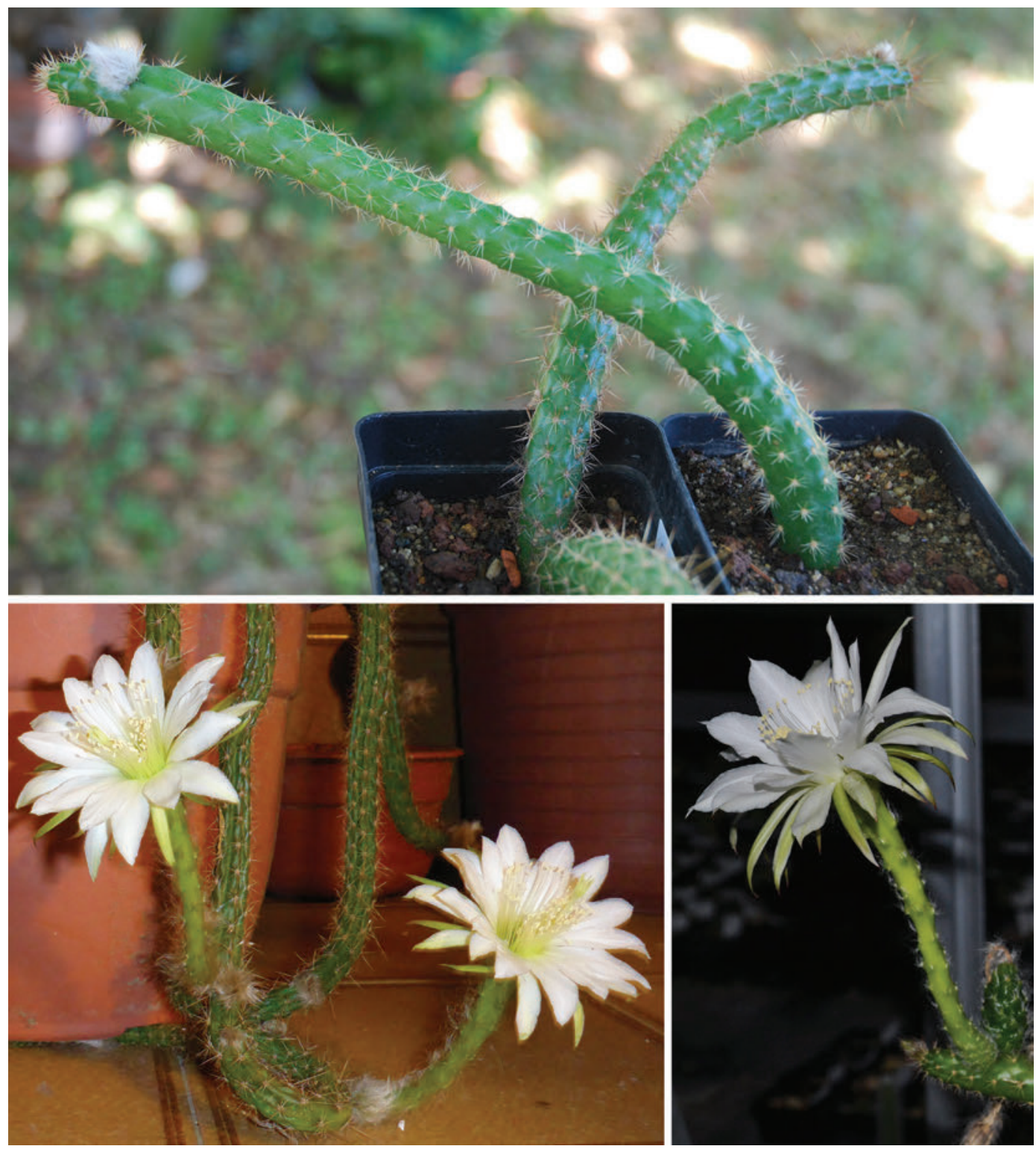

Figure 2. Top: left pot, new Trichocereus hahnianus finding; right pot, T. habnianus, HNT clone. Note the small hairy flower buds towards the tip of the stems; both plants grown in the greenhouse under the same sun light conditions. Scale: 7 $\times 7 \mathrm{~cm}$ square pots. Collection and picture, D. Schweich. Bottom: comparison of the flowers: left new clone (cultivated by R. Kiesling), right: HNT clone (cultivated by A. de Barmon).

firmed the close relationship to Echinopsis schickendantzii. Further related species of that clade are Echinopsis thelegona, E. camarguensis, and E. bridgesii, all species from the Eastern Andes of Argentina and Bolivia. The trees calculated on the basis of only one single marker showed in principle similar relationships as those of the two plastid markers (atpB-rbcL and $r p l 16$ ).

In a phylogenetic analysis of both morphological data and noncoding DNA sequence data (plastid markers trnL-F and $r p l 16$ ) Albesiano \& Terrazas (2012) came to a rather different conclusion: Harrisia hahniana turned out to be sister of Harrisia earlei in both analyses of the morphological and combined datasets, but sister to Echinopsis ancistrophora in the molecular two-marker data set. They approved the placement of $H$. hahniana (and $H$. earlei) in Trichocereus.

Guiggi (2012), without any explanation, but probably based on the analyses mentioned above, combined the species under Trichocereus as T. hahnianus (a combination unnecessarily repeated a few months later by Lodé 2013).

The generic position is uncertain if only morphological information is used. Kimnach (1987) remarked "There is no question that this has been a 


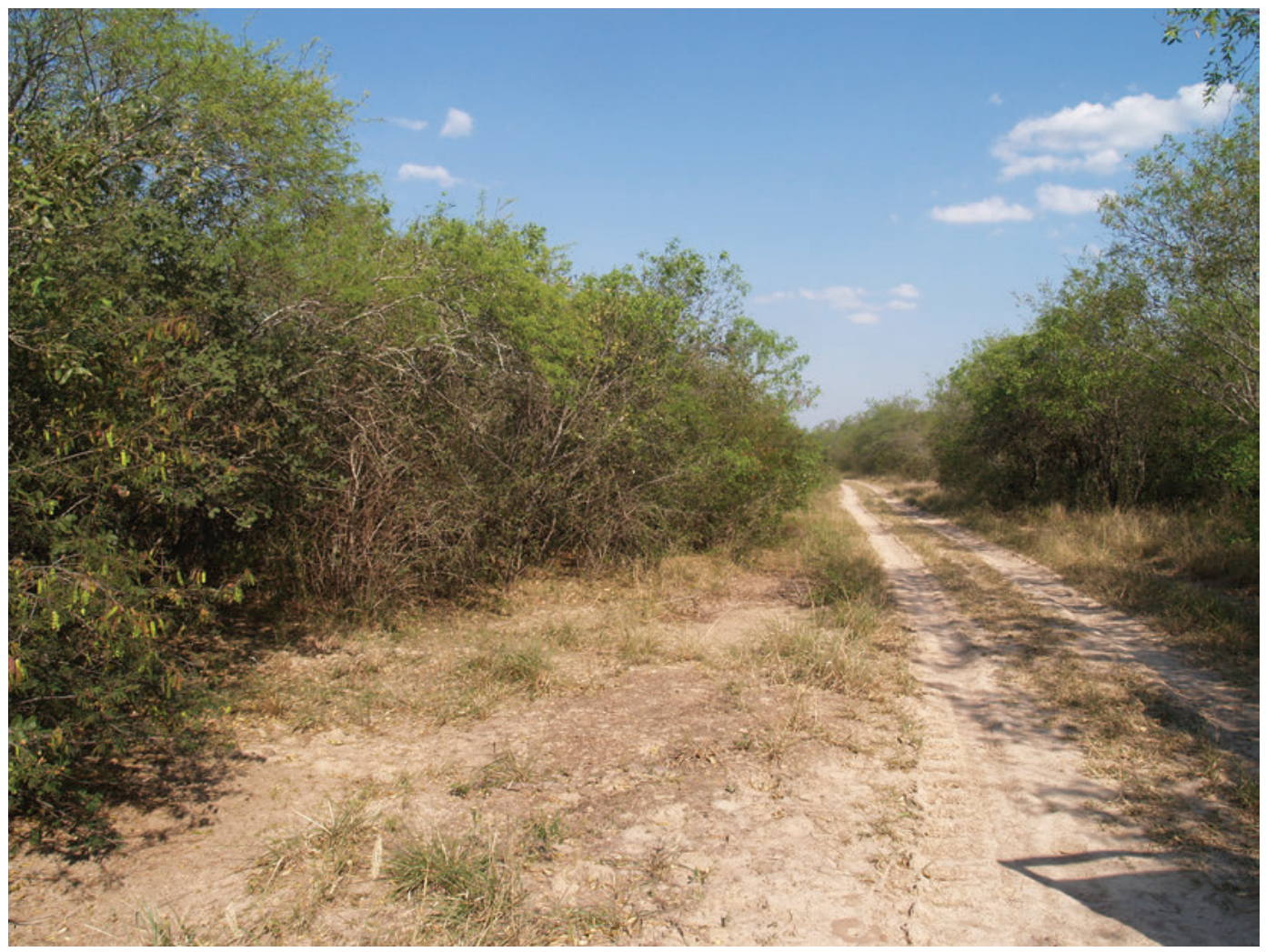

Figure 3. Typical woodland where Trichocereus hahnianus has been found.

difficult species to place generically", a circumstance already mentioned by Backeberg (1962) and true up to now, in spite of the great advances in scientific methods and knowledge. The stems resemble an Aporocactus, or some Selenicereus, although both are epiphytic and not terrestrial as M. hahnianus is. The flowers resemble Echinopsis more than Trichocereus, because the tube is thinner than the pericarpel and has only sparse hairs, although the buds are very hairy. The fruit is similar to that of Trichocereus because of the dense hair cover when young and the thick wall. Kimnach (1987) saw a similarity between the seeds of $M$. hahnianus and those of the genus Harrisia. According to our own observations, however, the seeds of $M$. hahnianus are much smaller than those of Harrisia and they don't have the cavernous hilum-micropylar-region typical for Harrisia seeds. The size of the seeds is comparable with the seeds of Trichocereus, but otherwise the similarity with the examined seeds of several Trichocereus species is not very high.

DNA analyses (Wallace 1997, Schlumpberger \& Renner 2012, Albesiano \& Terrazas 2012, Franck 2013) suggest that Mediocactus hahnianus belongs to the large and polyphyletic Echinopsis genus sensu lato, but the authors suggest using either Echinopsis, Trichocereus or Soehrensia as the genus name. We chose Trichocereus in the broad sense, i.e., based on morphological characters and including large columnar plants as well as small and low growing plants.
Soehrensia is an alternative suggested by DNA studies, but the flower size (at least) clearly conflicts the early diagnosis of Backeberg (1938). History and scientific progress will judge whether our choice is relevant or not, whereas the plants will remain unchanged.

The chromosome number of the new clone is already established with $2 \mathrm{n}=22$ (Las Peñas 2018). The relation of this species with some others (Echinopsis thelegona, E. camarguensis, E. bridgesii, $E$. vasquezii and E. arboricola, all with the same chromosome number $2 \mathrm{n}=22$; Las Peñas 2018) has been suggested by Franck et al. (2013).

\section{NOMENCLATURE AND DESCRIPTION}

Mediocactus hahnianus has been described with a short Latin diagnosis (only 2.5 lines) by Backeberg (1957), in order to validate novelties before the publication of his six-volume-monograph "Die Cactaceae" (Backeberg 1958-1962). In addition to the first description Backeberg (1959: 798) published a German translation with minor variants and very few details about the stem, but nothing about the flower and fruit, together with a picture of a (grafted) plant. More details were given by Backeberg (1962: 36533654), where he described the flower in detail, the fruit and briefly the seeds, and added a photo of the 
same specimen as in 1959, but with flowers, another photo with a dry flower, and one more with a hardly recognizable fruit. The flower photos were taken by Hahn's nephew Dieter Schneider, who had taken over the nursery after Hahn's death in 1954.

The epithet "hahnianus" was chosen after the horticulturist Adolph Hahn from Berlin, in whose nursery Backeberg had seen the plant (Backeberg 1959: 795).

\section{Trichocereus hahnianus (Backeb.) Guiggi,} Cactology 3 (Suppl. II): 5. 2012. Basionym: Mediocactus hahnianus Backeb., Descr. Cact. Nov.: 10. 1957.

$\equiv$ Harrisia hahniana (Backeb.) Kimnach \& Hutchison, Cact. Succ. J. (Los Angeles) 59: 59. 1987

$\equiv$ Echinopsis hahniana (Backeb.) R.S. Wallace, Cactaceae Consensus Init. 4: 12. 1997.

三Soehrensia hahniana (Backeb.) Schlumpb., Cactaceae Syst. Init. 28: 31. 2012.

= Selenicereus paraguayensis Hutch. ex Kimnach 1960. Nom. nud. (The name has been used on a herbarium label, only).

For types and other studied material see below.

Plant creeping, literally covering the soil, rooting when in contact with it. Stems fragile, cylindrical, not articulated, ca. 1.5-2.0 (-3.0) cm diameter, indefinite growth, up to $1 \mathrm{~m}$ long when pendent, branching from the base or lateral when injured, ca. 8 very low ribs when dehydrated, or tubercles slightly discernible when hydrated, epidermis fresh bright green, to dark, opaque green when grown at sunny places. Areoles at the edge of the ribs or on the center of the tubercles, felted and sporadically with some isolated long hairs. Spines thin, acicular (= needle shaped), very pungent, 8-14, whitish or yellowish or light-brownish-red when growing, 1 (-3) centrals rather porrect, $0.5-0.8 \mathrm{~cm}$ long, the others almost adpressed shorter, $0.3-0.8 \mathrm{~cm}$ long, when at full sun more differentiated, the central stronger, up to $1.0-2.5 \mathrm{~cm}$ long, radials $0.5 \mathrm{~cm}$ long.

Bud very woolly. Flowers nocturnal, from the young parts of the stems, $15.5-17.0 \mathrm{~cm}$ long, remaining open until the next morning and even the full day in overcast weather, delicate and fleeting smell of jasmine, at the anthesis funnelform or even rotate when fully open, $11.5-12.0 \mathrm{~cm}$ diameter; pericarpel slightly thicker than the tube; tube thin, ca. $1 \mathrm{~cm}$ diameter, with sparse adpressed scales, triangular and short at the base, lanceolate and longer near the throat, green to brown, with some white to brownish bristles up to $7 \mathrm{~mm}$ long and many whitish or brownish hairs, dense on the pericarpel, sparse on the tube. Sepaloid tepals green, narrow, acute; inner tepals pure white, obovate-oblong, acute, wide open at anthesis. Ovary chamber nearly globular 7-9 mm diameter. Stamens longer than the open perianth, with pale green base, whitish above, in two series, one along the tube 4-6 $\mathrm{cm}$ long, others at its upper part, shorter, in a single ring, anthers yellowish. Style cylindrical, whitish, ending in a yellowish or cream stigma 8-12-lobed. Fruit ovoid, longitudinally dehiscent, $32 \mathrm{~mm}$ long, $23 \mathrm{~mm}$ thick, with small (1.0-2.5 mm long) scales, epidermis smooth, shiny, green, covered by hairs, keeping or not the dried floral remains.

Seeds broadly obovate, blackish-brown, 1.25$1.50 \mathrm{~mm}$ long, ca. $1 \mathrm{~mm}$ wide and $0.75 \mathrm{~mm}$ thick, periphery slightly keeled, cells gradually smaller towards hilum, isodiametric, anticlinal boundaries channeled, straight; interstices cratered, relief convex, convexities low-domed, cuticle not or only weakly striate, hilum-micropylar-region oval, oblique, directed at ca. $45^{\circ}$ from main seed-axis, more or less curved, slightly sunken, bright, hilum and micropylar pores conspicuously separated.

Note: We have observed that in full sun the stems can reach up to $3 \mathrm{~cm}$ in diameter (Fig. 5). The seeds described by him are in coincidence with those obtained by A. de Barmon crossing the HNT clone (ISI 1594) of T. hahnianus with pollen of Echinopsis calochlora. The thin spines, 2-7 $\mathrm{mm}$ long at the pericarpel and 1-4 mm long at the fruit, mentioned by Kimnach, have not been observed at our material. The presence or absence and the different sizes of the bristles may be due to the development of individual flowers or fruits. The bristle size may have been observed by Kimnach on different specimens. Normally, the shorter bristles are found on flowers and the longer on fruits due they grow along maturation (accrescence).

\section{TYPIFICATION}

The species was described by Backeberg (1957), based on a plant in Hahn's nursery (Backeberg 1959: 795, 1962: 3653), but no type was designated by him. No plants or herbarium material from the original collection have remained, at least such are not known. The only material that could be considered as original material according to the Code (ICN Art 9.4; Turland, Wiersema, 2018) is the photo in Backeberg (1959: 798). Although Backeberg (1957) didn't cite the illustration, it is possible that the photo was made by him prior to, or at the time of, preparation of the diagnosis in the end of 1956. It is not clear from the text in Backeberg (1959: 795), whether he made the photo in the nursery of Dieter Schneider (that would mean in or after 1954) or already, when A. Hahn still was living. But it is likely that Backeberg had the necessary documentation together for the descriptions published in 1959 when he preferred to publish the diagnosis already earlier (Backeberg 1957). This concerns the typification now: If the photo is (the only known) element of the original material, it would have to be designated as lectotype. If not, a neotype has to be chosen. Since we can neither prove the one nor the other possibility, and since the original photo, which could perhaps give information about it, is not preserved, we consider it right to fix the name by a neotype. 
Already Kimnach (1987) intended to designate a neotype, but he failed when he cited more than one herbarium specimen at HNT, MO and US (ICN Art. 8.1), and contradicted Art. 8.2 (cf. Ex. 3) since the three specimens have been prepared at different times, irrespective of whether the material had been taken from the same, single clone in cultivation.

To validate the typification and to follow the intention of Kimnach as well the inscriptions at the herbarium specimens, we formally designate the neotype:

Neotype (designated here): Harrisia habniana (Mediocactus hahnianus); Paraguay, Rio Apa region, Rojas and West 8499, prep. ex cult. UCBG 37.1164-1 [by Kimnach] September 1976 (HNT 01738, photo seen). See Fig. 4. Isoneotypes: (F 1793761, seen; K 000100013, photo seen at: https://apps.kew.org/herbcat/ getImage.do?imageBarcode=K000100013).

Other studied material:

Mediocactus hahnianus; Paraguay, Rio Apa region, J. West 8499, prep. ex cult. [by Kimnach] August 12, 1953 (US 2756219, photo seen). https://collections. $\mathrm{nmnh}$. si.edu/search/botany/? $\mathrm{ti}=3$ (as Mediocactus hahnianus). Labeled as neotype.

Parodia sp.; Paraguay. Zwischen Rio Apa und Rio Aquidaban 1908/1909. K. Fiebrig 5318a, dated 1910, July 29. (K 000100014). Note: It consists of a small piece of a stem that apparently comes from T. habnianus; and a flower that perhaps belongs to Frailea sp. Later labeled "Echinopsis hahniana (Backeb.) R. Wallace” by N.P. Taylor in 2000. (https://apps.kew.org/herbcat/getImage. do? imageBarcode $=$ K000100014)

Selenicereus hahnianus; Paraguay, Rio Apa region, xerophytic. Limestone formation. 200 m? March 11, 1937. T. Rojas \& J. West 8499, prep. ex cult. [by P. Hutchison] Oct. 1952. (UC 1408638). (https://webapps.cspace.berkeley.edu/ucjeps/imageserver/blobs/ b33a53bd-a0c4-484e-a990/derivatives/OriginalJpeg/ content)

Echinopsis hahniana; Paraguay, Rio Apa. Grown at Lake Sarasota. Florida, obtained from Mesa Garden, Belen, New Mexico, International Succulent Introduction 1594. A. R. Franck 2645. 13 Jun. 2011 (USF). (http://swbiodiversity.org/seinet/collections/ individual/index.php?occid=19301579)

Echinopsis hahniana; USA, Sarasota Co., Lake Sarasota; cultivated, stem pendent. 6 August 2013, A.R. Franck 3266 (USF). (http://swbiodiversity.org/seinet/collections/individual/index. php?occid=19366667)

\section{TRICHOCEREUS HAHNIANUS IN CULTIVATION}

Upon cultivation, the cuttings collected by us in Paraguay immediately gave lateral roots, and grew fast. After some months, in summer, the plants freely produced several flowers but repeated hand-made pollination failed to produce fruits, confirming our impression that the cuttings are surely from a single clone, even though some had been collected at opposite sides of the population.

Some cuttings cultivated at more sunny places attracted our attention: they became thicker, and produced rigid, longer and unequal spines, more similar to some specimens of Monvillea cavendishii (Fig. 5). This similarity may explain why we failed to identify at the field other specimens which were probably confused with $M$. cavendishii when the hairy or nonhairy flowers are not seen.

A. de Barmon got seeds from the HNT clone pollinated with Echinopsis calochlora. Fruit development required much watering, and maturation was longer than in Echinopsis. Seeds were ripe within two months from pollination, but the fruit split in the next spring after watering was resumed. A ripe fruit has been obtained with viable seeds, which have given seedlings that are similar to the HNT clone. We don't know however whether the seeds resulted from a true pollination or from a pollinic stimulation by E. calochlora (Fig. 6). The seeds are also similar to those described by Kimnach (Fig. 7).

Crossing the new and the HNT clones has been attempted several times but it was unsuccessful until September $23^{\text {rd }}, 2019$. A fruit has developed and is still stuck to the stem on November $11^{\text {th }}$, whereas non-fertilized flowers dry and quickly fall off together with the pericarpel. We will see later whether the seeds are viable or not. Nevertheless, further studies are necessary to understand the pollination biology of T. hahnianus.

\section{OUTLOOK}

Presently, there are two documented clones: 1) the clone from the Huntington Botanical Garden that has been used by Kimnach for his studies and neotypification; 2) the new clone collected by us in Paraguay (Kiesling et al. 10536c). We will continue to cross-pollinate the two clones in order to get fruits and seeds. These as well as further plant material obtained from sowing have to be compared with the published data. In addition we will compare their morphology, cytology and DNA characters with putative related or morphologically similar species (Echinopsis serpentina, Lowry \& Mendoza 2011, from the border between Bolivia [La Paz] and Peru [Puno], in the Amazonian forest, a plant with very similar habit and flowers, as well with Trichocereus arboricola Kimnach and T. vasquezii Rausch).

The two well-identified clones are cultivated in the Systematics, Evolution and Cytogenetics Laboratory of Cactaceae (IMBIV-CONICET-UNC). Molecular phylogeny studies will be done to ascertain the position of this new clones within the phylogenies published by Schlumpberger \& Renner (2012) and Franck et al. (2013), using the same markers and others frequently used in these studies. Furthermore, cytogenetical and morphological characters will be mapped. 


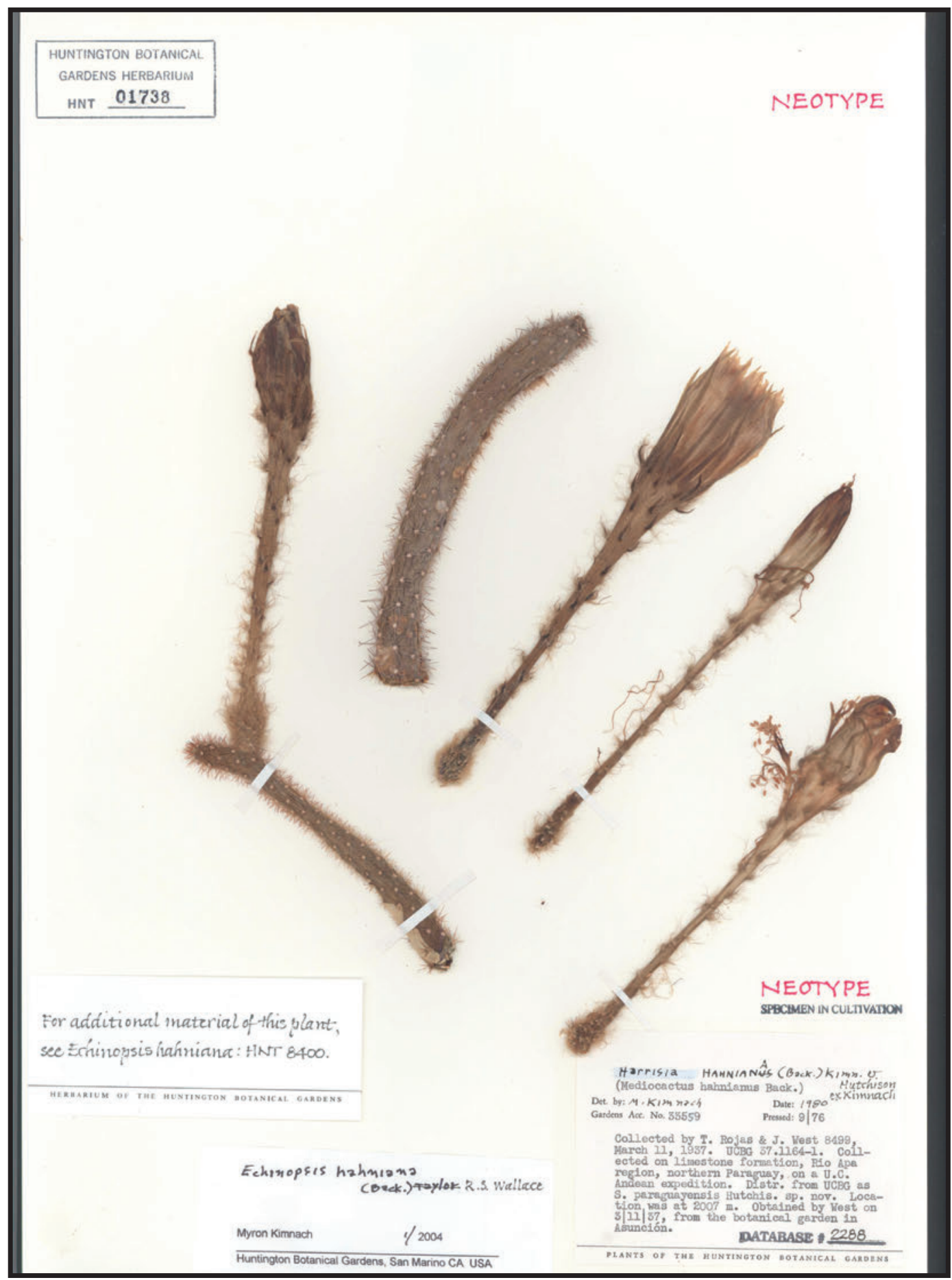

Figure 4. The designated neotype of Mediocactus habnianus.

\section{ACKNOWLEDGEMENTS}

The following persons, institutions and Society are gratefully acknowledged for their help and authorizations: The Huntington Botanical Gardens herbarium (San Marino, Ca.) for sending the image of the neotype specimen and the authorization to print it here; the Cactus and Succulent Society of America for the reproduction of the seed drawing of Kimnach published in 1987; R. Mottram (England) for the copy of Moser's article published in 1971; Ing. Agr. Germán González for helping us in the field; the members of the Paraguayan herbaria of Asunción, 

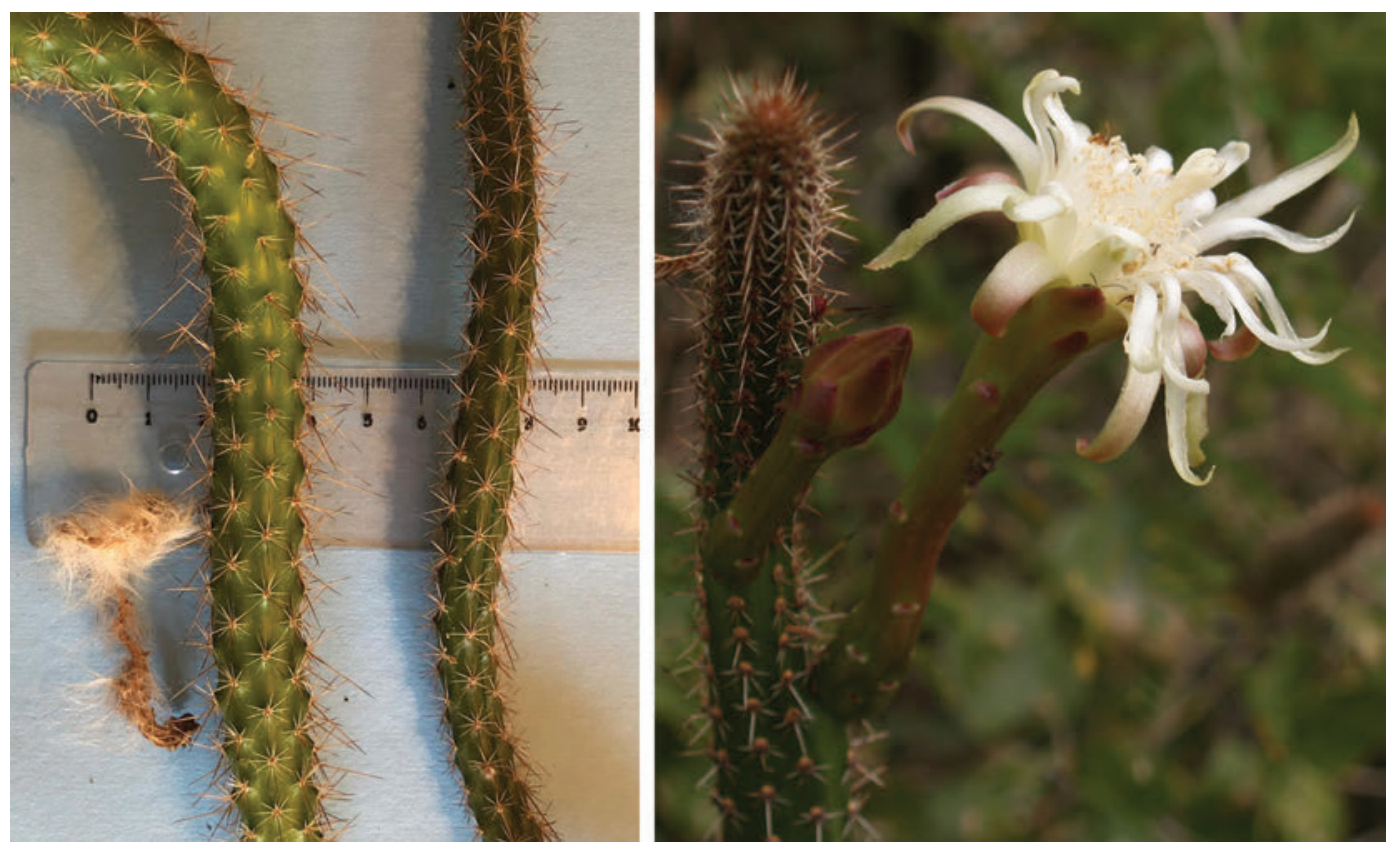

Figure 5. Left: comparison between the new Trichocereus hahnianus clone grown in full sun (left stem) and in the shade (right stem). Right: Monvillea cavendishii with the typical naked flower; the stem is thicker and spinier than T. hahnianus. However, without flower or fruit (red in M. cavendishii) the two plants can easily be confused.
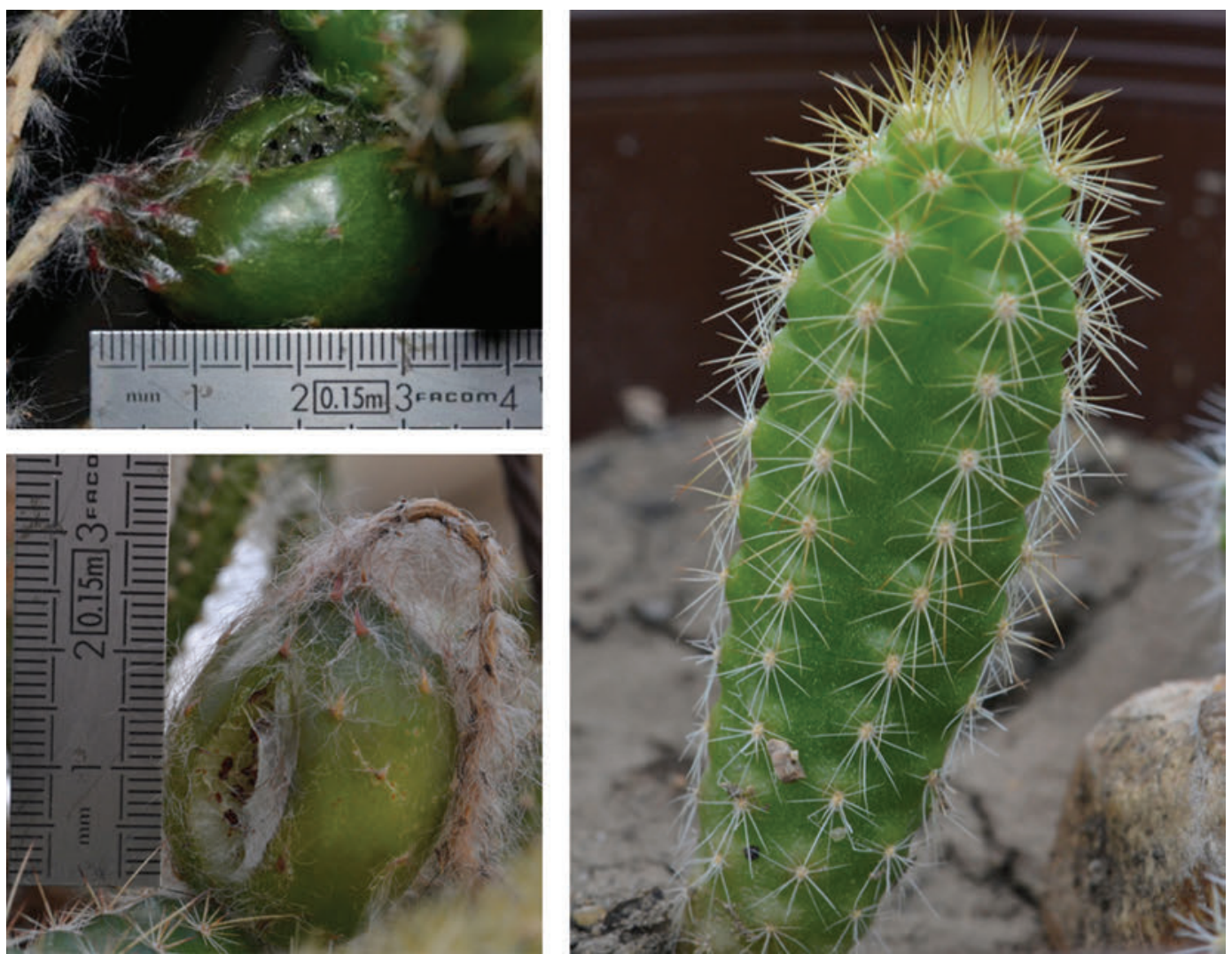

Figure 6. Left: longitudinally dehiscent fruit; top: HNT clone; bottom: new clone. Both clones pollinated with E. calochlora. Only the HNT clone has given viable seeds. Right: seedlings obtained from the HNT clone pollinated with $E$. calochlora; $55 \mathrm{~mm}$ high, $18 \mathrm{~mm}$ in diam., 7 ribs, 9 months old. Cultivation and pictures, A. de Barmon 


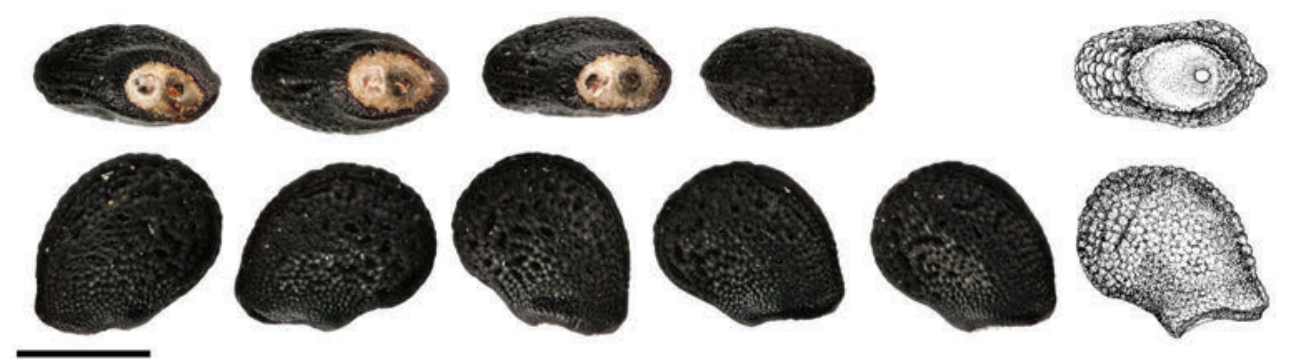

Figure 7. Comparison between hybrid seeds from the HNT (ISI 1594) clone $\times$ E. calochlora and Kimnach (1987) seed drawing (slightly adapted to fit the size of the photos). The black horizontal bar is $1 \mathrm{~mm}$ long. Photos: D. Metzing.

Facultad de Ciencias Químicas (FCQ), and Museo Nacional de Historia Natural (PY), for their collaboration, friendship, and guidance in the wild woodlands, as well as for the help to get the different permits; W. Papsch for the copy of Moser \& Valniček; the University \& Jepson Herbaria, University of California, Berkeley, for the information about specimens of $H$. hahniana available there and the collection data of J. West; the Cactus Mendoza nursery for the cultivation and attempt of cross pollination made with our provided material; the two reviewers for the profound revisions and helpful observations and corrections.

\section{REFFERENCES}

Albesiano S., Terrazas, T. 2012: Cladistic analysis of Trichocereus (Cactaceae: Cactoideae: Trichocereeae) based on morphological data and chloroplast DNA sequences. Haseltonia 17: 3-23.

Backeberg C. 1938. Die Diagnosen neuer Gattungen und Untergattungen. Blätter für Kakteenforschung 1938-6 [17].

Backeberg C. 1957 [dated 1956]. Descriptiones cactacearum novarum. G. Fischer. Jena. Germany.

Backeberg C. 1959-1962. Die Cactaceae. Handbuch der Kakteenkunde. 6 vols. G. Fischer. Jena. Germany.

Blossfeld H. 1935. A cactus collecting expedition in South America. The Cactus Journal 4: 25-34.

Bloßfeld H. 1936a. Eine Kakteen-Sammelreise in Südamerika. Kakteenkunde 1936: 24-27, 41-43, 61-64, 84-89, 110-112.

Blossfeld H. 1936b. A cactus collecting expedition in South America. Cactus and Succulent Journal (Los Angeles) 7: 147-155.

Blossfeld R. 1936. Preisliste für Samen von Kakteen und anderen Sukkulenten. Self-published, Potsdam. Germany. (https://www.cactuspro.com/lecture/Blossfeld/Blossfeld1936K360/)

Esser G. 1982. Vegetationsgliederung und Kakteenvegetation von Paraguay. Tropische und Subtropische Pflanzenwelt 38: 1-113, 1 map.

Franck A.R, Cochrane BJ, Garey JR. 2013. Phylogeny, biogeography, and infrageneric classification of Harrisia (Cactaceae). Systematic Botany 38: 210-223.

Guiggi A. 2012. Typification and new combinations in the genus Trichocereus (A. Berger) Riccobono. Cactology 3(suppl. II): 5. (http://www.cactus-mall.com/ cactology/Cactology\%20III\%20(Suppl\%20II).pdf)
Hunt D. (ed.) 2006. The new cactus lexicon. dh books, Milborne Port, England.

Kimnach M. 1987. Harrisia hahniana. Cactus and Succulent Journal (Los Angeles) 59: 59-62.

Las Peñas M.L. 2018. Cactaceae. In: Marhold, K., Kučera, J. (eds.), IAPT chromosome data 28. Taxon 67: 1235-1245.

Lodé J. 2013. New combinations. Cactus Adventures International 97: 2-3.

Lowry M. Mendoza M. 2011. Notes on cacti from the northwest of Bolivia with a new Echinopsis species. Cactus World 29: 95-102.

Metzing D. 1994. Cactaceae in Paraguay. Specie, ecologia e minaccia di estinzione. Piante Grasse Speciale 1993: 5-64.

Moser G. 1971. One species - three names? National Cactus and Succulent Journal 26: 4-5.

Moser G. 1985. Kakteen. Adolfo Maria Friedrich und sein schönes Paraguay. Self-published, Kufstein, Austria.

Moser G, Valniček J. 1967. Znovu o Gymnocalyciíchz Gran Chaca. Fričiana 7 (44): 3-11.

Schinini A. 2005. Teodoro Rojas. Biografía, viajes y especies dedicadas. Rojasiana 7: 101-149.

Schlumpberger BO. 2012: New combinations in the Echinopsis alliance. Cactaceae Systematics Initiatives 28: 29-31.

Schlumpberger B.O., Renner S.S. 2012. Molecular phylogenetics of Echinopsis (Cactaceae): polyphyly at all levels and convergent evolution of pollination modes and growth forms. American Journal of Botany 99: $1335-1349$.

Secretaría de Verde e do Meio Ambiente. Viveiros. 2012. São Paulo, Brazil. (https://www.prefeitura.sp.gov. $\mathrm{br} / \mathrm{cidade} / \mathrm{secretarias/upload/chamadas/livreto-vi-}$ veiros_1354643842.pdf)

Turland N.J., Wiersema J.H., Barrie, F.R., Greuter W., Hawksworth D.L., Herendeen, P.S., Knapp S., Kusber W.-H., Li D.-Z., Marhold K., May T.W., McNeill J., Monro A.M., Prado J., Price M.J., Smith G.F. 2018. International Code of Nomenclature for algae, fungi, and plants (Shenzhen Code). Koeltz Botanical Books. Germany. (https://www.iapt-taxon. org/nomen/pages/intro/title_page.html)

Vogt C. 2011. Composición de la flora vascular del Chaco Boreal, Paraguay I. Pteridophyta y Monocotiledoneae. Steviana 3: 13-47.

Wallace R. 1979. The phylogenetic position of Mediocactus habnianus. Cactaceae Consensus Initiatives 4: 11-12. 